\title{
Are there differences in nutrient intake of Brazilian adults according to weight status?
}

\author{
Há diferenças na ingestão de nutrientes de adultos brasileiros \\ segundo a condição de peso?
}

Marina Campos Araujo (https://orcid.org/0000-0002-7980-6618) ${ }^{1}$

Camilla de Chermont Prochnik Estima (https://orcid.org/0000-0002-5410-3940) ${ }^{2}$

Edna Massae Yokoo (http://orcid.org/0000-0002-3513-2084) ${ }^{3}$

Taís de Souza Lopes (http://orcid.org/0000-0002-6308-6214) ${ }^{4}$

Rosangela Alves Pereira (http://orcid.org/0000-0002-9886-9796) ${ }^{4}$

Rosely Sichieri (http://orcid.org/0000-0001-5286-5354) ${ }^{2}$

\footnotetext{
${ }^{1}$ Escola Nacional de Saúde Pública Sérgio Arouca, Fiocruz. R. Leopoldo Bulhões 1480/803, Bonsucesso. 21041-210 Rio de Janeiro RJ Brasil. mcamposaraujo@gmail.com ${ }^{2}$ Departamento de Epidemiologia, Instituto de Medicina Social, Universidade do Estado do Rio de Janeiro. Rio de Janeiro RJ Brasil. ${ }^{3}$ Departamento de Epidemiologia e Bioestatística, Universidade Federal Fluminense. Niterói RJ Brasil.

${ }^{4}$ Departamento de Nutrição Social e Aplicada, Universidade Federal do Rio de Janeiro. Rio de Janeiro RJ Brasil.
}

\begin{abstract}
It was assessed the intake and prevalence of inadequate nutrient intake according to weight status among Brazilian adults from urban areas $(n=16,198)$ evaluated in the Brazilian $\mathrm{Na}$ tional Dietary Survey (NDS - 2008-2009), that obtained food records from two non-consecutive days. The prevalence of inadequate nutrient intake according to weight status was estimated based on Brazilian and international recommendations, in which usual intake was estimated applying the National Cancer Institute method. From 14 nutrients evaluated, six differed according to weight status in men, and only two among women. For men, the mean proportion of energy derived from lipids and saturated fat and mean intake of cholesterol, zinc, and vitamin B12 were greater among those with excess weight compared to those with normal weight; the inverse was observed for dietary fiber. Mean sodium intake was greater and proportion of energy from added sugar intake was lower among obese women compared to overweight ones. Strategies to encourage food consumption with high micronutrient density should be targeted to adult population regardless of their weight status.

Key words Nutrients, Obesity, Diet surveys, Diet records
\end{abstract}

Resumo Avaliou-se a ingestão e a prevalência de ingestão inadequada de nutrientes segundo a condição de peso em adultos brasileiros de áreas urbanas ( $n=16.198$ ) investigados no Inquérito Nacional de Alimentação (INA 2008-2009), que obteve o registro alimentar de dois dias não consecutivos. A prevalência de inadequação da ingestão de nutrientes foi estimada segundo a condição de peso e com base em recomendações brasileiras $e$ internacionais, sendo a ingestão usual estimada pelo método do National Cancer Institute. Dos 14 nutrientes avaliados, seis diferiram segundo a condição de peso em homens e apenas dois entre as mulheres. Para os homens, a proporção média de energia proveniente dos lipídios e da gordura saturada e a ingestão média de colesterol, zinco e vitamina B12 eram mais elevadas para aqueles com excesso de peso do que entre os que tinham peso normal; o inverso foi observado para fibra dietética. A ingestão média de sódio foi maior e a proporção de ingestão de energia proveniente do açúcar de adição foi menor entre as mulheres obesas comparadas àquelas com sobrepeso. Estratégias para incentivar o consumo de alimentos com alta densidade de micronutrientes devem ser dirigidas à população adulta independentemente da sua condição de peso.

Palavras-chave Nutrientes, Obesidade, Inquéritos sobre dietas, Registros de dieta 


\section{Introduction}

The World Health Organization recognizes the obesity epidemic as an important target for the prevention and control of non-communicable diseases $(\mathrm{NCD})^{1}$. National survey data from the United States found lower intakes of micronutrients and higher prevalence of nutrient inadequacy among overweight and obese adults compared to normal weight ones ${ }^{2}$. Also, specific nutrients have been associated with obesity, such as blood deficiency of iron, zinc, or vitamins A, $\mathrm{C}$ and $\mathrm{E}^{3,4}$. Low blood concentrations of zinc, vitamin A or C in humans, for example, may decrease leptin expression, an adipokine connected with satiety ${ }^{3}$, and increase insulin resistance ${ }^{4}$, both effects that are related to adiposity. Iron and vitamin $\mathrm{E}$ were inversely associated with insulin and C-reactive protein ${ }^{4}$ and C-reactive protein has been directly associated with obesity in adults ${ }^{5}$. Moreover, García et al. ${ }^{6}$ reviewed the impact of micronutrient deficiencies on obesity and stated that antioxidants, such as vitamin C, vitamin $\mathrm{E}$ and $\mathrm{b}$-carotene, were predictors of the levels of leptin, which is closely related to obesity. However, this association may not represent a causal relationship and most guidelines have recommended reduced energy intake to prevent obesity regardless of diet composition? ${ }^{7}$.

Considering that nutrient biomarkers may be associated with obesity, we hypothesized whether nutrient intake and micronutrient intake inadequacy were different according weight status believing that overweight and obese adults have greater micronutrient intake inadequacy compared to normal weight individuals. We evaluated nutrient intake and inadequacies according to weight status in a large population based study, the first Brazilian National Dietary Survey (20082009) that showed important prevalence of micronutrient inadequate intake throughout all age groups $^{8-11}$.

\section{Subjects and Methods}

The National Dietary Survey (NDS) carried out in 2008-2009 was the first Brazilian nationwide survey of individual dietary intake. Design and sampling procedures are described elsewhere ${ }^{12}$. Briefly, a two-stage cluster sampling design was used. First, the primary sampling units, census tracts, were selected by systematic sampling and, afterwards households, the secondary sampling units, were selected by simple random sampling.
Individuals aged 10 years or older $(\mathrm{n}=34,003)$ living in 13,569 households from all five Brazilian Regions and urban and rural areas were included in the dietary survey. For this paper, only adults aged 20-59 years old from urban areas were included, excluding pregnant and lactating women $(\mathrm{n}=781)$, yielding a final sample of $16,198 \mathrm{Bra}$ zilian adults. The present study was approved by the local ethics committee.

Food records from two non-consecutive days were used to estimate food intake. Food nutritional composition was obtained in the Brazilian Table of Food Composition and in the Nutrient Data System for Research, version 2008 (Nutrition Coordinating Center, University of Minnesota, Minneapolis, MN, USA) $)^{13}$. The nutrient intake data did not include the consumption of supplements and/or medications.

Body weight was measured using a portable electronic scale with capacity of $150 \mathrm{~kg}$ and height was assessed using a portable stadiometer. Weight status was classified using the body mass index $\left(\mathrm{BMI}=\right.$ weight in $\mathrm{gram} / \mathrm{height}$ in $\left.\mathrm{cm}^{2}\right)$ classified according to the World Health Organization $(\mathrm{WHO})$ criteria $^{14}$.

\section{Data analyses}

The National Cancer Institute (NCI) method was used to estimate usual intake of energy, energy from protein, energy from carbohydrate, energy from added sugar, energy from lipids, energy from saturated fat, dietary fiber, cholesterol, calcium, iron, zinc, vitamins B12, A, C and sodium. The NCI method was also used to estimate the prevalence of nutritional inadequacy. This method estimates the usual intake after adjusting for within-person variance using the linear mixed effects model ${ }^{15}$. The technique of balanced repeated replication (BRR) was used to estimate standard errors ${ }^{16}$.

The prevalence of micronutrients inadequacy (except sodium and iron) was assessed through the Estimated Average Requirement (EAR) cut-off point method ${ }^{17-20}$, in which inadequacy denotes the proportion of population that consumed less than the median requirement. For sodium intake, inadequacy denotes excessively high intake [over the Tolerable Upper Intake Level $(U L)]^{21}$. For iron intake, the probability approach method was used ${ }^{22}$. The cut-off point for total cholesterol and energy from saturated fat followed the Brazilian Society of Cardiology recommendations ${ }^{23}$. Dietary Reference Intakes (DRI) were used to assess energy from protein, carbohydrates and 
lipids $^{24}$ and WHO recommendation were used for energy from added sugar ${ }^{25}$. For dietary fiber intake, we adopted a value of $25 \mathrm{~g} / \mathrm{d}$ considering a diet of $8368 \mathrm{~kJ}$ (2000 kcal), as recommended by the Brazilian Ministry of Health ${ }^{26}$. Nutrient intake means and inadequacy prevalence were estimated according to weight status.

The Goldberg method adapted by Black ${ }^{27}$ was used to define misreporting. Basal Metabolic Rates (BMR) were estimated ${ }^{28}$ and the ratios between reported energy intakes and BMRs ( $\mathrm{rEI}: \mathrm{BMR}$ ) were calculated along with the $95 \%$ confidence limits. Acceptable reporters were defined as having a rEI:BMR in the range 1.00 to 2.42 , under -reporters as a ratio $<1.00$, and over-reporters as a ratio $>2.42^{27}$.

NCI models used to estimate usual nutrient intake and prevalence of nutritional inadequacy included energy, age and misreporting as covariates. Macronutrient intake was analyzed a proportion of total energy intake and not considered energy intake as covariate.

Statistical significance analysis was performed by comparing the $95 \%$ confidence intervals. All statistical analyses were performed using survey procedures from SAS release 9.3 (2011, SAS Institute) to take into account weighting and the sample design effect considering the primary and secondary sampling units.

\section{Results}

Overall prevalence of overweight was 35\%, while that of obesity was $15 \%$. The prevalence of overweight was higher among men (40\%) than among women $(29 \%)$, whereas the prevalence of obesity was higher in women $(17 \%)$ than in men (13\%) (Table 1).

In both sexes, mean proportion of energy from protein was slightly higher among obese people. Among men, mean proportion of energy derived from total lipids and saturated fat total and mean intake of cholesterol, zinc, and vitamin B12 were greater among obese men compared to overweight and normal weight men. The inverse was observed for fiber intake. The mean of sodium intake was higher among obese women compared to overweight one. However, mean of added sugar intake was lower for obese compared to non-obese subjects. (Table 2).

Prevalence of inadequacy intake equal to or greater than $60 \%$ were observed for proportion of energy from added sugar, dietary fiber, calcium, sodium, and vitamin A among both men
Table 1. Prevalence of weight status and mean age among Brazilian adults (20-59 years old) from urban areas: The 2008-2009 National Dietary Survey.

\begin{tabular}{lllllll}
\hline & \multicolumn{2}{c}{ Total } & \multicolumn{2}{c}{ Men } & \multicolumn{2}{c}{ Women } \\
\hline & $\mathbf{n = 1 6} \mathbf{1 9 8}$ & $\mathbf{n = 7}$ & $\mathbf{4 4 1}$ & $\mathbf{n = 8}$ & $\mathbf{7 5 7}$ \\
\hline $\begin{array}{l}\text { Age (years) } \\
\text { [mean, standard } \\
\text { error: SE] }\end{array}$ & 37.7 & 0.2 & 37.9 & 0.2 & 38.1 & 0.2 \\
$\begin{array}{l}\text { Overweight } \\
(\mathrm{BMI} 25-29.9\end{array}$ & 34.9 & 0.6 & 40.5 & 0.9 & 29.5 & 0.8 \\
$\left.\mathrm{~kg} / \mathrm{m}^{2}\right)[\%, \mathrm{SE}]$ & & & & & & \\
$\begin{array}{l}\text { Obesity }(\mathrm{BMI} \\
\left.\geq 30 \mathrm{~kg} / \mathrm{m}^{2}\right)[\%, \\
\text { SE] }\end{array}$ & 14.8 & 0.5 & 12.8 & 0.6 & 16.8 & 0.7 \\
& & & & & & \\
\hline
\end{tabular}

and women regardless of weight status. The prevalence of inadequacy of energy from total lipids and saturated fat, cholesterol, and dietary fiber intake was greater among obese men compared to non-obese men. Alternatively, the prevalence of inadequate intake of zinc and vitamin B12 was lower among obese men compared to their counterparts. The prevalence of inadequacy of added sugar intake was lower among obese women compared to overweight and normal weight women (Table 3).

\section{Discussion}

Our hypothesis was not confirmed since the findings of this exploratory analysis showed that there were almost no differences in nutrient intake according to weight status, which suggests that nutrient inadequate intake might not be contributing to the development of obesity among Brazilian adults. Although obese men had excessive fat and low fiber intake compared to men of other weight status and obese women had excessive sodium intake compared to overweight, the mean values are close, and the prevalence of inadequate fat intake was low independently of weight status.

The higher zinc and vitamin B12 intake among obese men might be related to higher protein intake, mainly animal protein intake, since proportion of energy from protein was slightly higher among obese people. Brazilian national data of food intake showed that prevalence of all meat intake (beef, pork meat, chicken, processed meat) were greater among men than women ${ }^{29-31}$ 
Table 2. Adjusted mean intake ${ }^{\star}$ according to weight status among Brazilian adults (20-59 years old) from urban areas: The 2008-2009 National Dietary Survey.

\begin{tabular}{|c|c|c|c|c|c|c|}
\hline & \multicolumn{2}{|c|}{ Normal weight $\dagger$} & \multicolumn{2}{|c|}{ Overweight $\dagger$} & \multicolumn{2}{|c|}{ Obesity $\dagger$} \\
\hline & Mean & 95\% CI & Mean & $95 \% \mathrm{CI}$ & Mean & $95 \% \mathrm{CI}$ \\
\hline $\operatorname{Men}(n=7441)$ & \multicolumn{2}{|c|}{$(n=3643)$} & \multicolumn{2}{|c|}{$(\mathrm{n}=2824)$} & \multicolumn{2}{|c|}{$(\mathrm{n}=974)$} \\
\hline Energy $(\mathrm{kJ}) \ddagger$ & 8870 & $8643 ; 9097$ & 8995 & $8791 ; 9199$ & 9164 & $8735 ; 9592$ \\
\hline Energy from protein (\%) & 16.9 & $16.6 ; 17.1$ & 17.4 & $17.0 ; 17.7$ & 17.4 & $17.1 ; 17.8$ \\
\hline Energy from carbohydrate (\%) & 55.4 & $55.0 ; 55.8$ & 54.3 & $53.8 ; 54.8$ & 53.2 & $52.3 ; 54.1$ \\
\hline Energy from added sugar (\%) & 13.0 & $12.5 ; 13.6$ & 13.1 & $12.4 ; 13.9$ & 12.5 & $12.2 ; 12.8$ \\
\hline Energy from lipids (\%) & 26.9 & $26.7 ; 27.1$ & 27.4 & $27.2 ; 27.6$ & 27.9 & $27.6 ; 28.3$ \\
\hline Energy from saturated fat (\%) & 9.1 & $9.0 ; 9.2$ & 9.4 & $9.3 ; 9.4$ & 9.7 & $9.6 ; 9.8$ \\
\hline Cholesterol (mg) & 272 & $267 ; 278$ & 277 & $269 ; 285$ & 295 & $287 ; 302$ \\
\hline Dietary fiber $(\mathrm{g} / 4184 \mathrm{~kJ})$ & 11.1 & $10.8 ; 11.4$ & 10.8 & $10.3 ; 11.3$ & 10.2 & $9.8 ; 10.7$ \\
\hline Calcium (mg) & 548 & $521 ; 576$ & 577 & $569 ; 584$ & 582 & $561 ; 602$ \\
\hline Iron (mg) & 13.4 & $13.1 ; 13.6$ & 13.6 & $13.2 ; 13.9$ & 13.5 & $13.0 ; 13.9$ \\
\hline Zinc (mg) & 12.7 & $12.1 ; 13.2$ & 13.2 & $12.8 ; 13.5$ & 14.1 & $13.8 ; 14.3$ \\
\hline Vitamin B12 $(\mu \mathrm{g})$ & 5.1 & $4.9 ; 5.3$ & 5.5 & $5.3 ; 5.7$ & 6.0 & $5.6 ; 6.3$ \\
\hline Vitamin $\mathrm{A}(\mu \mathrm{g}) \S$ & 435 & $405 ; 465$ & 457 & $431 ; 482$ & 451 & $409 ; 494$ \\
\hline Vitamin C (mg) & 119 & $111 ; 127$ & 132 & $126 ; 137$ & 136 & $116 ; 156$ \\
\hline Sodium (mg) & 3605 & $3560 ; 3650$ & 3697 & $3598 ; 3797$ & 3648 & $3576 ; 3721$ \\
\hline Women $(n=8757)$ & \multicolumn{2}{|c|}{$(n=4713)$} & \multicolumn{2}{|c|}{$(n=2620)$} & \multicolumn{2}{|c|}{$(n=1424)$} \\
\hline Energy $(\mathrm{kJ}) \ddagger$ & 7216 & $6954 ; 7479$ & 6985 & $6798 ; 7173$ & 7113 & $6893 ; 7333$ \\
\hline Energy from protein (\%) & 16.6 & $16.3 ; 16.9$ & 16.4 & $16.2 ; 16.7$ & 17.2 & $17.0 ; 17.4$ \\
\hline Energy from carbohydrate (\%) & 56.2 & $56.0 ; 56.5$ & 56.1 & $55.6 ; 56.6$ & 55.7 & $55.2 ; 56.2$ \\
\hline Energy from added sugar (\%) & 14.9 & $14.5 ; 15.3$ & 14.7 & $14.2 ; 15.1$ & 13.2 & $12.9 ; 13.5$ \\
\hline Energy from lipids (\%) & 27.3 & $27.0 ; 27.6$ & 27.6 & $27.4 ; 27.8$ & 27.5 & $27.1 ; 27.8$ \\
\hline Energy from saturated fat (\%) & 9.6 & $9.5 ; 9.8$ & 9.7 & $9.6 ; 9.9$ & 9.5 & $9.4 ; 9.6$ \\
\hline Cholesterol (mg) & 229 & $217 ; 242$ & 218 & $212 ; 225$ & 232 & $212 ; 252$ \\
\hline Dietary fiber $(\mathrm{g} / 4184 \mathrm{~kJ})$ & 10.7 & $10.4 ; 10.9$ & 10.6 & $10.4 ; 10.9$ & 10.9 & $10.6 ; 11.3$ \\
\hline Calcium (mg) & 498 & $483 ; 512$ & 463 & $433 ; 494$ & 468 & $445 ; 490$ \\
\hline$(20-50$ years $)$ & 499 & $479 ; 519$ & 458 & $425 ; 492$ & 447 & $428 ; 465$ \\
\hline (51-59 years) & 497 & $460 ; 534$ & 481 & $437 ; 524$ & 523 & $482 ; 563$ \\
\hline Iron (mg) & 10.2 & $9.8 ; 10.6$ & 9.7 & $9.6 ; 9.8$ & 10.2 & $9.7 ; 10.7$ \\
\hline (20-50 years) & 10.3 & $9.9 ; 10.8$ & 9.8 & $9.7 ; 9.9$ & 10.3 & $9.9 ; 10.7$ \\
\hline (51-59 years) & 9.3 & $9.0 ; 9.6$ & 9.4 & $8.9 ; 9.9$ & 10.0 & $9.2 ; 10.8$ \\
\hline Zinc (mg) & 9.9 & $9.6 ; 10.2$ & 9.5 & $9.3 ; 9.8$ & 10.3 & $9.6 ; 11.0$ \\
\hline Vitamin B12 $(\mu \mathrm{g})$ & 4.2 & $4.0 ; 4.4$ & 4.1 & $4.0 ; 4.1$ & 4.3 & $4.0 ; 4.7$ \\
\hline Vitamin A $(\mu g) \S$ & 440 & $409 ; 471$ & 433 & $416 ; 451$ & 431 & $408 ; 454$ \\
\hline Vitamin C (mg) & 128 & $120 ; 137$ & 123 & $115 ; 132$ & 115 & $103 ; 126$ \\
\hline Sodium (mg) & 2811 & $2738 ; 2883$ & 2735 & $2717 ; 2754$ & 2907 & $2817 ; 2998$ \\
\hline
\end{tabular}

while men had lower prevalence of vegetables and fruit intake compared to women ${ }^{12,32}$.

The finding that obese women have a lower intake of excessive added sugar compared to overweight and normal weight women indicates a possible substitution of added sugar for artificial sweeteners and/or low sugar products among obese women, since analyses were adjusted for misreporting. Furthermore, the lower intake of added sugar among obese women was accompanied by quite similar energy intake across the weight status groups, indicating that the reduction of added sugar among obese women was offset by an increase in other energy sources.

Few studies compared nutrient intake across the categories of weight status. Agarwal et al. ${ }^{2}$ 
Table 3. Cut-off points to define inadequate intake ${ }^{\star}$, and prevalence of inadequate nutrient intake according to weight status among Brazilian adults (20-59 years old) from urban areas: The 2008-2009 National Dietary Survey.

\begin{tabular}{|c|c|c|c|c|c|c|c|}
\hline & \multicolumn{7}{|c|}{ Prevalence of inadequacy } \\
\hline & \multirow[t]{2}{*}{ Cut-off point } & \multicolumn{2}{|c|}{ Normal weight $\dagger$} & \multicolumn{2}{|c|}{ Overweight $\dagger$} & \multicolumn{2}{|c|}{ Obesity $\dagger$} \\
\hline & & $\%$ & $95 \% \mathrm{CI}$ & $\%$ & $95 \% \mathrm{CI}$ & $\%$ & $95 \% \mathrm{CI}$ \\
\hline \multicolumn{8}{|l|}{$\operatorname{Men}(n=7441)$} \\
\hline Energy $(\mathrm{kJ}) \ddagger$ & & - & - & - & - & - & - \\
\hline Energy from protein (\%) & $<10 \%$ & 0.2 & $0.1 ; 0.3$ & 0.1 & $0.03 ; 0.2$ & 0.1 & $0.05 ; 0.2$ \\
\hline Energy from carbohydrate (\%) & $>65 \%$ & 7 & $6 ; 7$ & 5 & $4 ; 6$ & 3 & $2 ; 4$ \\
\hline Energy from added sugar (\%) & $>10 \%$ & 67 & $64 ; 69$ & 67 & $64 ; 71$ & 63 & $59 ; 67$ \\
\hline Energy from lipids (\%) & $>35 \%$ & 4 & $4 ; 5$ & 5 & $5 ; 6$ & 7 & $6 ; 7$ \\
\hline Energy from saturated fat (\%) & $>10 \%$ & 33 & $31 ; 35$ & 37 & $36 ; 38$ & 42 & $40 ; 44$ \\
\hline Cholesterol (mg) & $>300 \mathrm{mg}$ & 36 & $34 ; 38$ & 37 & $34 ; 40$ & 42 & $39 ; 45$ \\
\hline Dietary fiber $(\mathrm{g} / 4184 \mathrm{~kJ})$ & $<12.5 \mathrm{~g} / 4184 \mathrm{~kJ}$ & 70 & $66 ; 74$ & 74 & $69 ; 79$ & 79 & $74 ; 84$ \\
\hline Calcium (mg) & $<800 \mathrm{mg}$ & 85 & $83 ; 88$ & 82 & $81 ; 83$ & 82 & $79 ; 84$ \\
\hline Iron (mg) & - & 5 & - & 5 & - & 4 & - \\
\hline Zinc (mg) & $<9.4 \mathrm{mg}$ & 28 & $26 ; 31$ & 27 & $24 ; 30$ & 22 & $19 ; 25$ \\
\hline Vitamin B12 $(\mu \mathrm{g})$ & $<2 \mu \mathrm{g}$ & 9 & $7 ; 10$ & 7 & $5 ; 8$ & 5 & $4 ; 5$ \\
\hline Vitamin A $(\mu \mathrm{g}) \S$ & $<625 \mu \mathrm{g}$ & 82 & $79 ; 85$ & 79 & $76 ; 83$ & 80 & $76 ; 84$ \\
\hline Vitamin C (mg) & $<75 \mathrm{mg}$ & 49 & $46 ; 53$ & 45 & $44 ; 46$ & 44 & $40 ; 48$ \\
\hline Sodium (mg) & $>2300 \mathrm{mg}$ & 87 & $86 ; 87$ & 88 & $87 ; 89$ & 88 & $87 ; 89$ \\
\hline \multicolumn{8}{|l|}{ Women $(n=8757)$} \\
\hline Energy $(\mathrm{kJ}) \ddagger$ & - & - & - & - & - & - & - \\
\hline Energy from protein (\%) & $<10 \%$ & 0.3 & $0.2 ; 0.4$ & 0.3 & $0.2 ; 0.5$ & 0.2 & $0.1 ; 0.3$ \\
\hline Energy from carbohydrate (\%) & $>65 \%$ & 8 & $7 ; 10$ & 8 & $7 ; 9$ & 7 & $6 ; 8$ \\
\hline Energy from added sugar (\%) & $>10 \%$ & 77 & $74 ; 80$ & 76 & $74 ; 78$ & 68 & $65 ; 70$ \\
\hline Energy from lipids (\%) & $>35 \%$ & 5 & $4 ; 6$ & 6 & $5 ; 6$ & 6 & $5 ; 7$ \\
\hline Energy from saturated fat (\%) & $>10 \%$ & 41 & $39 ; 44$ & 43 & $41 ; 45$ & 39 & $38 ; 41$ \\
\hline Cholesterol (mg) & $>300 \mathrm{mg}$ & 21 & $17 ; 24$ & 18 & $16 ; 21$ & 23 & $16 ; 30$ \\
\hline Dietary fiber (g/4184kJ) & $<12.5 \mathrm{~g} / 4184 \mathrm{~kJ}$ & 75 & $72 ; 78$ & 75 & $72 ; 78$ & 72 & $68 ; 76$ \\
\hline Calcium (mg) & & - & - & - & - & - & - \\
\hline (20-50 years) & $<800 \mathrm{mg}$ & 82 & $81 ; 83$ & 91 & $89 ; 94$ & 92 & $91 ; 93$ \\
\hline (51-59 years) & $<1000 \mathrm{mg}$ & 96 & $94 ; 98$ & 96 & $95 ; 98$ & 95 & $94 ; 97$ \\
\hline Iron (mg) & & - & - & - & - & - & - \\
\hline (20-50 years) & - & 31 & - & 35 & - & 32 & - \\
\hline (51-59 years) & - & 34 & - & 35 & - & 36 & - \\
\hline Zinc (mg) & $<6.8 \mathrm{mg}$ & 20 & $19 ; 22$ & 25 & $24 ; 26$ & 21 & $18 ; 25$ \\
\hline Vitamin B12 $(\mu \mathrm{g})$ & $<2 \mu \mathrm{g}$ & 12 & $10 ; 14$ & 15 & $13 ; 18$ & 13 & $11 ; 15$ \\
\hline Vitamin A $(\mu \mathrm{g}) \S$ & $<500 \mu \mathrm{g}$ & 68 & $64 ; 72$ & 69 & $67 ; 71$ & 70 & $67 ; 73$ \\
\hline Vitamin C (mg) & $<60 \mathrm{mg}$ & 36 & $34 ; 38$ & 38 & $35 ; 40$ & 41 & $37 ; 46$ \\
\hline Sodium (mg) & $>2300 \mathrm{mg}$ & 70 & $68 ; 73$ & 65 & $63 ; 67$ & 68 & $66 ; 71$ \\
\hline
\end{tabular}

${ }^{*}$ Cut-off point was based on Estimated Average Requirement for calcium, zinc, vitamins B12, A, C, and sodium. The probability approach method was used for iron. Brazilian Society of Cardiology recommendations were used for total cholesterol and energy from saturated fat. Dietary Reference Intakes were used for energy from protein, carbohydrates and lipids. WHO recommendation were used for energy from added sugar. Brazilian Ministry of Health recommendation was used for dietary fiber intake. $†$ Normal weight $=$ BMI $<25 \mathrm{~kg} / \mathrm{m}^{2} ;$ Overweight $=$ BMI $25-29.9 \mathrm{~kg} / \mathrm{m}^{2} ;$ Obesity $=$ BMI $\geq 30 \mathrm{~kg} / \mathrm{m}^{2} . \ddagger 1 \mathrm{~kJ}=0.239 \mathrm{kcal}$. $\$$ Calculated as retinol activity equivalents.

compared micronutrient intake according to weight status among adults from National Health and Nutrition Examination Survey (NHANES) 2001-2008. Different from our results, the authors found that obese adults had about $5 \%$ to
$12 \%$ lower micronutrient intake and a significantly greater prevalence of inadequate intake of vitamin $A$, vitamin $C$, vitamin $D$, vitamin $E$, calcium, and magnesium intake compared to normal weight adults. However, most of stu- 
dies analyzed diet quality or nutrient deficiency using blood biomarkers ${ }^{3,4,33-35}$. Results from the 2008-2009 NDS, the same survey used in the present study, showed that low diet quality was characterized by processed foods with high energy and low micronutrient density, and reduced fruit and vegetables consumption ${ }^{36}$. However, it was not investigated diet quality according to weight status. Recent studies have identified low diet quality, based on analysis of food and nutrient intake, among obese people from both sexes and of different ages, socioeconomic status and culture ${ }^{33,34,37}$. Nonetheless, studies that focused on differences on micronutrient biomarkers blood levels and obesity or obesity inflammation markers are controversial. García et al. ${ }^{3}$ observed an inverse association between blood concentrations of vitamins $\mathrm{C}$ and $\mathrm{E}$ with BMI and adiposity and a direct association between serum vitamin A and leptin concentrations among Mexican women. In another study, García et al. ${ }^{4}$ found an inverse association between serum iron and vitamin $\mathrm{E}$ with insulin concentrations and resistance. In addition, Zavala et al. ${ }^{35}$ found that zinc blood concentrations were inversely associated with inflammatory cytokines present in populations with high prevalence of obesity. While the same study have not shown any evidence of vitamins $\mathrm{C}$ and $\mathrm{E}$ blood concentrations related to obesity inflammation markers among rural Mexican women. Nevertheless, it is noteworthy that these findings were obtained in special population groups or in clinical settings. We could not directly compare our results with those results because they used nutrient blood concentrations and obesity inflammation markers.
Although our objective was evaluate diet quality, based on nutrient intake e nutrient inadequate intake, according to weight status, it is important to mention that nutrient intake may not reflect the blood concentrations of nutrients. Nutrient status is determined not only by its total intake, but also by a number of factors that include its food sources (chemical form), nutrients and components interactions, nutrient metabolism, and so on ${ }^{38}$.

A limitation of this study was that our data were based mainly on an American food composition table. This table was used since some foods, recipes, cooking methods, and nutrients information were not available in Brazilian food composition table. We recognized that some nutrients intake could be over- or underestimated compared to actual Brazilian food composition. However, we did a detailed verification of discrepancies between both nutritional composition databases in order to minimize nutrient over- or underestimate. Detailed information about these critical analyses can be found elsewhere ${ }^{13}$. In addition, American recommendations were used as cut-off point for nutrient inadequacy intake since we do not have Brazilians values established.

This nationwide dataset from a large middle-income country suggests that nutrient intake and inadequacies of nutrient intake are independent of weight status. This can be particularly important in non-obese people, who are not the priority group for public health strategies focusing on decreasing prevalence of obesity. Strategies to encourage consumption of food with high micronutrient density should cover all adult population regardless of their weight status. 


\section{Collaborations}

MC Araujo contributed to the analysis and interpretation of the data, manuscript conception and writing; CCP Estima and EM Yokoo contributed to the interpretation of the data and manuscript writing; TS Lopes contributed to the analysis; RA Pereira and R Sichieri contributed to the design of the study, analysis and interpretation of the data, and manuscript writing. All authors read and approved the final manuscript.

\section{Acknowledgements}

The survey was funded by the Ministry of Health of Brazil. MC Araujo received a fellowship from the Brazilian Federal Agency for the Improvement of Higher Education (Coordenação de Aperfeiçoamento de Pessoal de Nível Superior - CAPES).

\section{References}

1. World Health Organization (WHO). Global action plan for the prevention and control of noncommunicable diseases 2013-2020. Geneva: WHO Document Production Services; 2013.

2. Agarwal S, Reider C, Brooks JR, Fulgoni VL. Comparison of prevalence of inadequate nutrient intake based on body weight status of adults in the United States: an analysis of NHANES 2001-2008. J Am Coll Nutr 2015; 34(2):126-134.

3. García OP, Ronquillo D, Caamaño M del C, Camacho M, Long KZ, Rosado JL. Zinc, vitamin A, and vitamin $\mathrm{C}$ status are associated with leptin concentrations and obesity in Mexican women: results from a cross-sectional study. Nutr Metab 2012; 9(1):59.

4. García OP, Ronquillo D, Caamaño M del C, Martínez G, Camacho M, López V, Rosado JL. Zinc, Iron and Vitamins A, C and E are Associated with Obesity, Inflammation, Lipid Profile and insulin Resistance in Mexican School-Aged Children. Nutrients 2013; 5(12):5012-5030.

5. Zeba AN, Delisle HF, Rossier C, Renier G. Association of high-sensitivity C-reactive protein with cardiometabolic risk factors and micronutrient deficiencies in adults of Ouagadougou, Burkina Faso. Br J Nutr 2012; 109(7):1266-1275.

6. García OP, Long KZ, Rosado JL. Impact of micronutrient deficiencies on obesity. Nutr Rev 2009; 67(10):559-572.

7. Jensen MD, Ryan DH, Apovian CM, Ard JD, Comuzzie AG, Donato KA, Hu FB, Hubbard VS, Jakicic JM, Kushner RF, Loria CM, Millen BE, Nonas CA, PiSunyer FX, Stevens J, Stevens VJ, Wadden TA, Wolfe BM, Yanovski SZ, Jordan HS, Kendall KA, Lux LJ, Mentor-Marcel R, Morgan LC, Trisolini MG, Wnek J, Anderson JL, Halperin JL, Albert NM, Bozkurt B, Brindis RG, Curtis LH, DeMets D, Hochman JS, Kovacs RJ, Ohman EM, Pressler SJ, Sellke FW, Shen WK, Smith Junior SC, Tomaselli GF. 2013 AHA/ACC/TOS guideline for the management of overweight and obesity in adults: a report of the American College of Cardiology/American Heart Association Task Force on Practice Guidelines and The Obesity Society. Circulation 2014; 129(Supl. 2):S102-138.

8. Araujo MC, Verly Junior E, Junger WL, Sichieri R. Independent association of income and education with nutrient intake in Brazilian adults: 2008-2009 National Dietary Survey. Public Health Nutr 2014; 17(12):2740-2752.

9. Araujo MC, Bezerra IN, Barbosa FS, Junger WL, Yokoo EM, Pereira RA, Sichieri R. Consumo de macronutrientes e ingestão inadequada de micronutrientes em adultos. Rev Saude Publica 2013; 47(Supl. 1):S177-S189.

10. Veiga GV, Costa RS, Araujo MC, Moura AS, Bezerra IN, Barbosa FS, Sichieri R, Pereira RA. Inadequação do consumo de nutrientes entre adolescentes brasileiros. Rev Saude Publica 2013; 47(Supl. 1):S212-S221.

11. Fisberg RM, Marchioni DML, Castro MA, Verly Junior E, Araujo MC, Bezerra IN, Pereira RA, Sichieri R. Ingestão inadequada de nutrientes na população de idosos do Brasil: Inquérito Nacional de Alimentação 2008-2009. Rev Saude Publica 2013; 47(Supl. 1):S222-S230. 
12. Instituto Brasileiro de Geografia e Estatística (IBGE). Pesquisa de Orçamentos Familiares, 2008-2009. Análise do Consumo Alimentar Pessoal no Brasil. Rio de Janeiro: IBGE; 2011.

13. Instituto Brasileiro de Geografia e Estatística (IBGE). Pesquisa de Orçamentos Familiares, 2008-2009. Tabela de composição nutricional dos alimentos consumidos no Brasil. Rio de Janeiro: IBGE; 2011.

14. World Health Organization (WHO). Physical status: the use and interpretation of anthropometry: report of a WHO Expert Committee. Geneva: WHO Technical Report Series; 1995.

15. Tooze JA, Midthune D, Dodd KW, Freedman LS, Krebs-Smith SM, Subar AF, Guenther PM, Carroll RJ, Kipnis V. A new statistical method for estimating the usual intake of episodically consumed foods with application to their distribution. J Am Diet Assoc 2006; 106(10):1575-1587.

16. Barbosa F dos S, Junger WL, Sichieri R. Assessing usual dietary intake in complex sample design surveys. Rev Saude Publica 2013; 47(Supl. 1):S171-S176.

17. Institute of Medicine, Food and Nutrition Board (IOM). Dietary Reference Intakes for thiamin, riboflavin, niacin, vitamin B6, folate, vitamin B12, pantothenic Acid, biotin, and choline. Washington: National Academy Press; 1998.

18. Institute of Medicine, Food and Nutrition Board (IOM). Dietary Reference Intakes for vitamin C, vitamin E, selenium, and carotenoids. Washington: National Academy Press; 2000.

19. Institute of Medicine, Food and Nutrition Board (IOM). Dietary Reference Intakes for vitamin A, vitamin $K$, arsenic, boron, chromium, copper, iodine, iron, manganese, molybdenum, nickel, silicon, vanadium, and zinc. Washington: National Academy Press; 2001.

20. Institute of Medicine, Food and Nutrition Board (IOM). Dietary Reference Intakes for calcium and vitamin D. Washington: National Academy Press; 2010.

21. Institute of Medicine, Food and Nutrition Board (IOM). Dietary Reference Intakes for water, potassium, sodium, chloride, sulfate. Washington: National Academy Press; 2004.

22. Institute of Medicine, Food and Nutrition Board (IOM). Dietary Reference Intakes: Applications in Dietary Assessment. Washington: National Academy Press; 2000.

23. Sposito AC, Caramelli B, Fonseca FA, Bertolami MC; Brazilian Society of Cardiology. IV Brazilian Guideline for Dyslipidemia and Atherosclerosis prevention: Department of Atherosclerosis of Brazilian Society of Cardiology. Arq Bras Cardiol 2007; 88(Supl. 1):S2-S19.

24. Institute of Medicine. Dietary Reference Intakes for Energy, Carbohydrate, Fiber, Fat, Fatty Acids, Cholesterol, Protein, and Amino Acids. Washington: The National Academies Press; 2002.

25. World Health Organization (WHO). Diet, Nutrition and the Prevention of Chronic Diseases. Geneva: WHO; 2003. Joint WHO/FAO Expert Consultation. WHO Technical Report Series no. 916.

26. Brasil. Ministério da Saúde (MS). Guia alimentar para a população brasileira: promovendo a alimentação saudável. Brasília: MS; 2006.
27. Black AE. Critical evaluation of energy intake using the Goldberg cut-off for energy intake:basal metabolic rate. A practical guide to its calculation, use and limitations. Int J Obes 2000; 24(9):1119-1130.

28. Schofield WN, Schofield C, James WPT. Basal metabolic rate-review and prediction, with an annotated bibliography of source material. Hum Nutr Clin Nutr 1985; 39C:1-96.

29. Carvalho A, César C, Fisberg R, Marchioni D. Excessive meat consumption in Brazil: Diet quality and environmental impacts. Public Health Nutr 2013; 16(10):1893-1899.

30. Avila JC, Luz VG, Assumpção D de, Fisberg RM, Barros MBA. Meat intake among adults: a population-based study in the city of Campinas, Brazil. A cross-sectional study. Sao Paulo Med J 2016; 134(2):138-145.

31. Carvalho AM, César CL, Fisberg RM, Marchioni DM. Meat Consumption in Sao Paulo - Brazil: Trend in the Last Decade. PLoS One 2014; 9:e96667.

32. Mondini L, Moraes SA, Freitas ICM, Gimeno SGA. Fruit and vegetable intake by adults in Ribeirão Preto, Southeastern Brazil. Rev Saude Publica 2010; 44(4):686-694.

33. Duan R, Liu Y, Xue H, Yang M, Cheng G. Cross-sectional association between overall diet quality and overweight/obesity among children and adolescents in Chengdu. Zhonghua Liu Xing Bing Xue Za Zhi 2014; 35(9):994-998.

34. Yu SH, Song Y, Park M, Kim SH, Shin S, Joung H. Relationship between adhering to dietary guidelines and the risk of obesity in Korean children. Nutr Res Pract 2014; 8(6):705-712.

35. Zavala G, Long KZ, García OP, Caamaño M del C, Aguilar T, Salgado LM, Rosado JL. Specific micronutrient concentrations are associated with inflammatory cytokines in a rural population of Mexican women with a high prevalence of obesity. Br J Nutr 2013; 109(4):686-694.

36. Souza AM, Pereira RA, Yokoo EM, Levy RB, Sichieri R. Most consumed foods in Brazil: National Dietary Survey 2008-2009. Rev Saude Publica 2013; 47(Supl. 1):S190-S199.

37. Ventura VA, Fonseca VM, Ramos EG, Marinheiro LP, Souza RA, Chaves CRM, Peixoto MV. Association between quality of the diet and cardiometabolic risk factors in postmenopausal women. Nutr J 2014; 13:121.

38. Odriozola L, Corrales FJ. Discovery of nutritional biomarkers: future directions based on omics technologies. Int J Food Sci Nutr 2015; 66(Supl. 1):S31-40.

Artigo apresentado em 16/02/2017

Aprovado em 19/09/2017

Versão final apresentada em 21/09/2017 